\title{
SISTEM PENDUKUNG KEPUTUSAN PEMBERIAN KREDIT SEPEDA MOTOR MENGGUNAKAN METODE SIMPLE ADDITIVE WEIGHTING (SAW) PADA PT. NSS CABANG KEFAMENANU
}

\author{
Yoseph P.K.Kelen', Siprianus S.Manek² \\ ${ }^{1,2}$ Teknologi Informasi, Universitas Timor, Kefamenanu, Indonesia \\ 1'yosepkelen@unimor.ac.id, ${ }^{2}$ siprianusmanek@unimor.ac.id
}

\begin{abstract}
ABSTRAK
PT.Nusantara Surya Sakti (NSS) adalah perusahaan yang bergerak di bidang jasa pembiayaan dengan berkonsentrasi kepada pembiayaan sepeda motor Honda. Perusahaan ini turut berinovasi untuk menjadi solusi pembiayaan bagi kebutuhan masyarakat dengan membuka berbagai macam jenis pembiayaan lainnya seperti pembiayaan multiproduk, mesin pertanian, motor dan mobil. Dalam melancarkan bisnisnya, PT.NSS telah menetapkan kebijakan dalam pemberian kredit yaitu calon penerima kredit harus memenuhi syarat Five C, bagaimana karakter nasabah (Character), kapasitas melunasi kredit (Capacity), kemampuan modal yang dimiliki nasabah (Capital), jaminan yang dimiliki nasabah untuk menanggung resiko kredit (Collateral) dan kondisi keuangan nasabah (Condition). Namun, jumlah data pemohon kredit yang banyak membuat pihak PT.NSS kesulitan menganalisa dan memutuskan konsumen yang tepat untuk mendapatkan kredit. Jika terjadi kesalahan dalam pemilihan calon penerima kredit, maka akan terjadi kemacetan kredit konsumen yang menimbulkan kerugian yang dapat manghambat laju perkembangan perusahaan. Berdasarkan masalah di atas, maka diperlukan sebuah sistem pendukung keputusan (SPK) terkomputerisasi yang dapat menganalisa data pemohon kredit dan menentukan keputusan dengan cepat. Metode perhitungan yang digunakan pada SPK ini adalah Simple Additive Weighting (SAW).
\end{abstract}

Kata Kunci : pembiayaan, sepeda motor, SAW, kredit, sistem

\begin{abstract}
PT.Nusantara Surya Sakti (NSS). is a company engaged in the field of financing services by concentrating on financing Honda motorcycles. The company is also innovating to become a financing solution for people's needs by opening up various other types of financing such as multiproduct financing, agricultural machinery, motorcycles and cars. In launching its business, PT. NSS has established a policy in granting credit that prospective credit recipients must meet the requirements of Five C, how the character of the customer (Character), capacity to pay off credit (Capacity), the ability of capital owned by customers (Capital), collateral owned by customers to bear credit risk (Collateral) and the customer's financial condition (Condition). However, the large amount of credit applicant data makes it difficult for PT.NSS to analyze and decide the right consumer to get credit. If there is an error in the selection of prospective credit recipients, there will be a consumer credit jam that will cause losses that can hamper the rate of development of the company. Based on the above problem, we need a computerized decision support system (SPK) that can analyze credit applicant data and determine decisions quickly. The calculation method used in this SPK is Simple Additive Weighting (SAW).
\end{abstract}

Keywords : finance, motorcycle, SAW, credit, system 
Jurnal Ilmiah Ilmu Komputer Vol. 5, No. 2, September 2019

Fakultas Ilmu Komputer

Universitas AL Asyariah Mandar

\section{PENDAHULUAN}

PT.Nusantara Surya Sakti (NSS) adalah perusahaan yang bergerak di bidang jasa pembiayaan dengan berkonsentrasi kepada pembiayaan sepeda motor Honda. Seiring pertumbuhan dan perkembangan kebutuhan masyarakat perusahaan ini turut berinovasi untuk menjadi solusi pembiayaan bagi kebutuhan masyarakat dengan membuka berbagai macam jenis pembiayaan lainnya seperti pembiayaan multiproduk, mesin pertanian, dan mobil. NSS telah terdaftar dalam Asosiasi Perusahaan Pembiayaan Indonesia (APPI) dan Biro Kredit, serta diawasi oleh Otoritas Jasa Keuangan (OJK).

Dalam melancarkan bisnisnya, PT.NSS telah menetapkan kebijakan dalam pemberian kredit yaitu calon penerima kredit harus memenuhi syarat Five $\mathrm{C}$, bagaimana karakter nasabah (Character), kapasitas melunasi kredit (Capacity), kemampuan modal yang dimiliki nasabah (Capital), jaminan yang dimiliki nasabah untuk menanggung resiko kredit (Collateral) dan kondisi keuangan nasabah (Condition). Namun, jumlah data pemohon kredit yang banyak membuat pihak PT.NSS kesulitan menganalisa dan memutuskan konsumen yang tepat untuk mendapatkan kredit. Jika terjadi kesalahan dalam pemilihan calon penerima kredit, maka akan terjadi kemacetan kredit konsumen yang menimbulkan kerugian yang dapat manghambat laju perkembangan perusahaan.

Berdasarkan masalah di atas, maka diperlukan sebuah sistem pendukung keputusan (SPK) terkomputerisasi yang dapat menganalisa data pemohon kredit dan menentukan keputusan dengan cepat. Sistem ini dirancang untuk mendukung seluruh tahap pengambilan keputusan mulai dari mengidentifikasikan masalah, memilih data yang relevan, dan menentukan pendekatan yang digunakan dalam proses pengambilan keputusan sampai mengevaluasi pemilihan alternatif-alternatif yang ada. Metode perhitungan yang digunakan pada SPK ini adalah Simple Additive Weighting (SAW). Konsep dasar dari metode SAW adalah mencari bobot terakhir dari bentuk hasil penilaian setiap alternatif dari semua atribut.

\section{TINJAUAN PUSTAKA}

\subsection{Tinjauan Pustaka}

Sistem pendukung keputusan adalah proses pengambilan keputusan dibantu menggunakan komputer untuk membantu pengambil keputusan dengan menggunakan beberapa data dan model tertentu untuk menyelesaikan beberapa masalah yang tidak terstruktur [1].

Sebuah SPK diharapkan memiliki beberapa karakteristik sebagai berikut:1.Dukungan untuk pengambil keputusan, terutama pada situasi semiterstruktur dan tak terstruktur, dengan menyertakan penilaian manusia dan informasi terkomputerisasi.2.Dukungan untuk semua level manajerial.3.Dukungan untuk keputusan independen dan atau sekuensial.4. Dukungan di semua fase proses pengambilan keputusan: inteligensi, desain, pilihan dan implementasi.5.Dukungan diberbagai proses dan gaya pengambilan keputusan.6. Adaptivitas sepanjang waktu.7 Peningkatan terhadap keefektifan pengambilan keputusan (akurasi, timelines, kualitas) ketimbang pada efisiensinya (biaya pengambilan keputusan).8.Kontrol penuh oleh pengambil keputusan terhadap semua langkah proses pengambilan keputusan dalam memecahkan suatu masalah.9.Pengguna akhir dapat mengembangkan dan memodifikasi sendiri sistem sederhana.10.Kapabilitas pemodelan memungkinkan eksperimen dengan berbagai strategi yang berbeda di bawah konfigurasi yang berbeda.

Karakteristik dari SPK tersebut membolehkan para pengambil keputusan untuk membuat keputusan yang lebih baik dan lebih konsisten pada satu cara yang dibatasi waktu.Tujuan dari sistem pendukung keputusan yaitu : 1.Menerapkan konsep sistem pendukung keputusan dalam rangka membantu pengambilan keputusan.2.Membantu dalam mengantisipasi perubahan yang mungkin terjadi pada setiap pelaksanaan program kegiatan [2] .

Tiga tahapan dalam proses pengambilan keputusan yaitu:1.Tahap Intellegence, adalah tahap proses pengenalan persoalan melalui penyelidikan lingkungan untuk mengetahui ada atau tidaknya masalah. Kesimpulan dari penyelidikan diperoleh dari pengolahan data dengan metode yang telah ditetapkan sebelumnya atau dengan metode khusus. Aliran informasi bergerak dari tingkatan manajemen terendah menuju tingkatan manajemen tertinggi.2.Tahap Design, merupakan tahap mencari, analisis serta perumusan alternative tindakan yang akan diambil. Pada tahap design ini, sistem informasi harus mampu membuat keputusan - keputusan.3.Tahap Choice, merupakan tahap memilih suatu tindakan yang paling tepat dari beberapa alternatif yang telah dirumuskan [3]. Langkah selanjutnya adalah pelaksanaan alternatif terpilih. Bila suatu alternatif telah dilaksanakan, fungsi informasi berubah menjadi pengumpul data untuk selanjutnya, merupakan umpan balik.

Pengertian kredit dalam arti ekonomi adalah suatu penundaan pembayaran, yaitu uang atau barang (prestasi) yang diterima sekarang akan dikembalikan pada masa yang akan datang berikut tambahan suatu kontra prestasi. Berdasarkan definisi kredit, maka pihak meminjam berkewajiban melunasi hutangnya setelah jangka waktu tertentu dengan jumah bunga yang telah ditentukan [4].

Konsep dasar metode SAW adalah mencari penjumlahan terbobot dari rating kinerja pada setiap alternatif pada semua atribut. Metode SAW membutuhkan proses normalisasi matrix keputusan ke suatu skala yang dapat diperbandingkan dengan semua rating alternatif yang ada [5].

Penggunaan konsep Fuzzy memudahkan pengguna untuk melakukan analisa pada nilai,bobot dan level kriteria yang digunakan dalam proses perhitungan dan perangkingan dengan menggunakan metode Simple Additive Weighting (SAW). Analisis hasil perhitungan yang didapatkan bisa menjadi rekomendasi bagi pihakpihak pengambil keputusan [6]. Dari hasil perancangan 
Jurnal Ilmiah Ilmu Komputer Vol. 5, No. 2, September 2019

Fakultas Ilmu Komputer

Universitas AL Asyariah Mandar

penjadwalan distribusi pada PT NSS Cabang Kefamenanu dengan menggunakan metode Distribution Requirement Planning (DRP) dapat mengatasi permasalahan pemenuhan kebutuhan produk dimana meminimasi penumpukan dan kekosongan persediaan produk pada setiap warehouse (Kelen, Y. P. K., \& Sikas, O. R., 2019).

\subsection{Gambar dan Tabel}

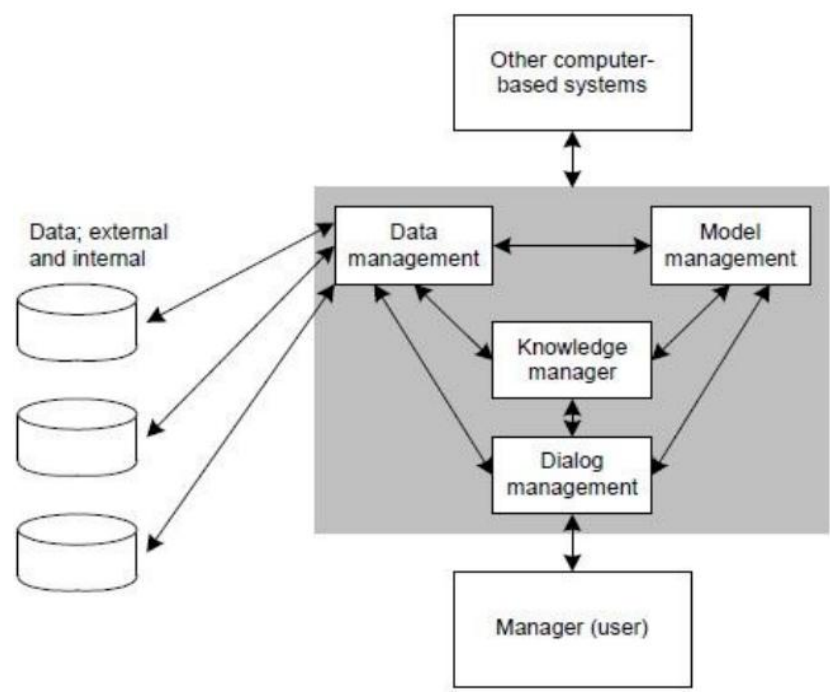

Gambar 1. Skematik SPK (Turban dkk, 2005)

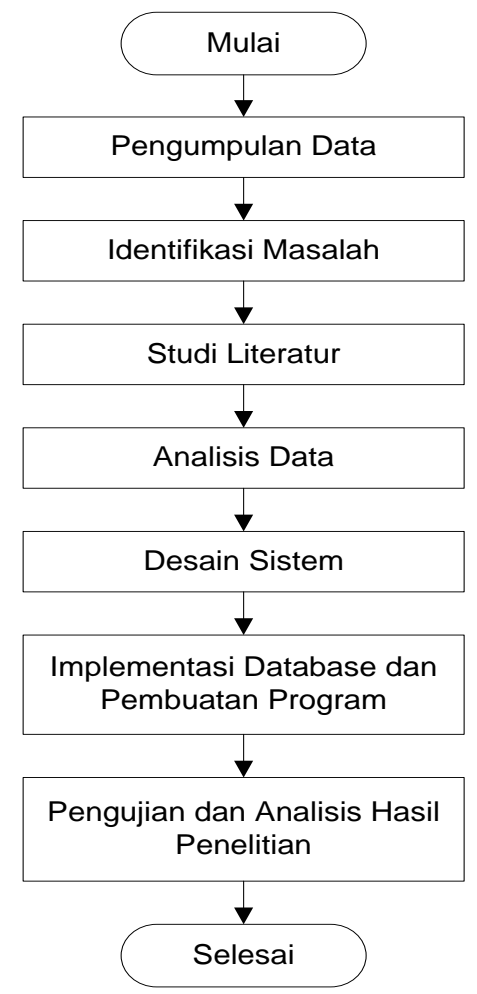

Gambar 2. Prosedur Penelitian
(P) ISSN 2442-451X

(O) ISSN 2503-3832

PT. Nusantara Salkti Kefannenanu

\begin{tabular}{|c|c|c|c|c|c|c|}
\hline \multirow{2}{*}{ TYPE MOTOR } & \multirow{2}{*}{ UANG MUKA } & \multirow{2}{*}{\multicolumn{5}{|c|}{$\frac{\text { TENOR }}{23}$}} \\
\hline & & & 17 & 23 & 29 & \\
\hline \multirow{3}{*}{$\begin{array}{l}\text { REVO FIT FI } \\
16.339 .000\end{array}$} & 1.500 .000 & 1.755 .000 & 1.255.000 & 1.010 .000 & 865.000 & 769.000 \\
\hline & 1.800 .000 & 1.710 .000 & 1.230 .000 & 985.000 & 842.000 & 752.000 \\
\hline & 2.0000 .000 & 1.697.000 & 1.210 .000 & 970.000 & 838.000 & 742.000 \\
\hline \multirow{3}{*}{$\begin{array}{l}\text { REVOX X JTT } \\
\text { 18.039.000 }\end{array}$} & 2.000 .000 & 1.870 .000 & 1.330 .000 & 1.065 .000 & 925.000 & 820.000 \\
\hline & 2.500 .000 & 1.815 .000 & 1.285 .000 & 1.025 .000 & 895.000 & 798.000 \\
\hline & 3.000 .0000 & 1.765 .000 & 1.240 .000 & 999.000 & 868.000 & 775.000 \\
\hline \multirow{3}{*}{$\begin{array}{l}\text { Beat Sporty CW JKT } \\
18.199 .000\end{array}$} & 1.500 .000 & 1.925.000 & 1.365.000 & 1.090 .000 & 945.000 & 845.000 \\
\hline & 2.0000 .000 & 1.868.000 & 1.315.000 & 1.058 .000 & 870.000 & 775.000 \\
\hline & 2.500 .000 & 1.835.000 & 1.280 .000 & 1.027 .000 & 835.000 & 745.000 \\
\hline \multirow{3}{*}{$\begin{array}{c}\text { Beat Sporty CBS JKT } \\
18.399 .000 \\
\end{array}$} & 2.000 .0000 & 1.945 .000 & 1.375 .000 & 1.125.000 & 920.000 & 835.000 \\
\hline & 2.500 .0000 & 1.915 .000 & 1.340 .000 & 1.085 .000 & 890.000 & 810.000 \\
\hline & 3.000 .0000 & 1.780 .000 & 1.290 .000 & 1.055 .000 & 865.000 & 780.000 \\
\hline \multirow{3}{*}{$\begin{array}{c}\text { Beat SP CBS ISS JKT } \\
18.849 .000 \\
\end{array}$} & 2.000 .000 & 1.965 .000 & 1.390 .000 & 1.135 .000 & 940.000 & 845.000 \\
\hline & 2.500 .000 & 1.920 .000 & 1.350 .000 & 1.090 .000 & 9910.000 & 820.000 \\
\hline & 3.000.0000 & 1.865.000 & 1.310 .000 & 1.060 .000 & 8755.000 & 790.000 \\
\hline \multirow{3}{*}{$\begin{array}{l}\text { Beat Street CBS JKT } \\
18.849 .000\end{array}$} & 2.000 .0000 & 1.965 .000 & 1.390 .000 & 1.135 .000 & 940.000 & 845.000 \\
\hline & 2.500 .0000 & 1.920 .000 & $\begin{array}{l}1.350 .000 \\
\end{array}$ & 1.090 .0000 & $\begin{array}{l}910.000 \\
9100\end{array}$ & 820.000 \\
\hline & 3.0000 .000 & 1.865 .000 & 1.3130 .000 & 1.066 .0000 & 875.000 & 790.000 \\
\hline \multirow{3}{*}{$\begin{array}{c}\text { SCOOPY STYLISH JKT } \\
20.920 .000\end{array}$} & 2.500 .000 & 2.165 .000 & 1.563 .000 & 1.245 .000 & 1.065 .000 & 965.000 \\
\hline & 3.500 .000 & 205000 & 1.450 .0000 & 1.1950 .000 & 1.025 .000 & 925.000 \\
\hline & $\frac{2.5000 .000}{2.500}$ & 2.365 .000 & $\begin{array}{l}1.460 .000 \\
1.680 .000\end{array}$ & $\begin{array}{l}1.165 .000 \\
1.365 .000\end{array}$ & $\begin{array}{l}999.5000 \\
1.165 .000\end{array}$ & $\begin{array}{l}8966.000 \\
1.065 .000\end{array}$ \\
\hline \multirow{2}{*}{$\begin{array}{c}\text { VARIO } 125 \text { CBS ISS JKT } \\
22.644 .000\end{array}$} & 3.000 .000 & 2.295 .000 & 1.645 .000 & 1.325 .000 & 1.145 .000 & 1.025 .000 \\
\hline & 3.500.000 & 2.245 .000 & 1.595 .000 & 1.285 .000 & 1.115 .000 & 1.010 .000 \\
\hline \multirow{3}{*}{$\begin{array}{l}\text { VARIO } 150 \text { JKT } \\
24.954 .000\end{array}$} & 3.000 .000 & 2.455 .000 & 1.750 .000 & 1.415 .000 & 1.215 .000 & 1.095 .000 \\
\hline & 3.500.000 & 2.393.000 & 1.715 .000 & 1.378 .000 & 1.185 .000 & 1.075 .000 \\
\hline & 4.0000.000 & 2.330 .000 & 1.665.000 & 1.345 .000 & 1.165.000 & 1.045 .000 \\
\hline \multirow{3}{*}{$\begin{array}{l}\text { SUPRA X } 125 \mathrm{CW} \text { JKT } \\
20.759 .000\end{array}$} & 3.000 .000 & 2.130 .000 & 1.510 .000 & 1.235 .000 & 1.055 .000 & 945.000 \\
\hline & 3.500 .000 & 2.075 .000 & 1.465.000 & 1.195.000 & 1.010 .000 & 915.000 \\
\hline & 4.000 .000 & 2.015 .000 & 1.420 .000 & 1.165.000 & 995.000 & 895.000 \\
\hline \multirow{3}{*}{$\begin{array}{l}\text { SUPRA GTR } 150 \text { SPORTY } \\
25.049 .000\end{array}$} & 3.500 .000 & 2.545.000 & 1.815 .000 & 1.475 .000 & 1.280 .000 & 1.135 .000 \\
\hline & 4.000.0000 & 2.480 .000 & 1.775 .000 & 1.445 .000 & 1.255 .000 & 1.125 .000 \\
\hline & 4.500.0000 & 2.425 .000 & $\begin{array}{l}1.735 .000 \\
\end{array}$ & 1.420 .000 & 1.225 .000 & 1.095 .000 \\
\hline \multirow{3}{*}{$\begin{array}{c}\text { SONIC 150 JKT } \\
25.404 .000\end{array}$} & 4.000.0000 & 2.375 .000 & 1.625 .000 & 1.275 .000 & 1.085 .000 & 995.000 \\
\hline & & 2.286 .000 & 1.585 .000 & 1.245 .000 & 1.058 .000 & 965.000 \\
\hline & 5.000 .000 & 2.245 .000 & 1.545 .000 & 1.225 .000 & 1.03. & 920.000 \\
\hline \multirow{3}{*}{$\begin{array}{c}\text { CB } 150 \text { Verza CW JKT } \\
22.493 .000\end{array}$} & 3.5000 .0000 & $\frac{2.235 .000}{2.2500}$ & $\begin{array}{l}1.535 .0000 \\
1.5450\end{array}$ & 1.200 .0000 & 1.1.100.000 & 995.000 \\
\hline & 4.000 .000 & 2.183 .000 & 0.345 & 1.263 .000 & 1.075 .000 & 968.000 \\
\hline & $\begin{array}{l}4.5000000 \\
5.000 .000\end{array}$ & 29280000 & $\begin{array}{l}2.0755 .0000 \\
\end{array}$ & 1.16750000 & 1.4250000 & $\frac{935.000}{1280000}$ \\
\hline \multirow{2}{*}{$\begin{array}{c}\text { CB150R STFR JKT CL } \\
29.986 .000\end{array}$} & 5.500 .000 & 2.872 .000 & 2.037 .000 & 1.645 .000 & 1.398 .000 & 1.255 .000 \\
\hline & 6.000 .000 & 2.815 .000 & 1.995 .000 & 1.615 .000 & 1.371 .000 & 1.231 .000 \\
\hline \multirow{3}{*}{$\begin{array}{l}\text { CRF 150L JKT } \\
35.823 .000\end{array}$} & 5.000.000 & 3.591.000 & 2.650 .000 & 2.080 .000 & 1.800 .000 & 1.617 .000 \\
\hline & 5.500 .000 & 3.477 .000 & 2.560 .000 & 2.015 .000 & 1.744 .000 & 1.566.000 \\
\hline & 6.000 .000 & 3.364.000 & 2.479 .000 & 1.950 .000 & 1.688 .000 & 1.516 .000 \\
\hline \multicolumn{3}{|l|}{ 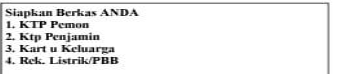 } & & & & \\
\hline
\end{tabular}

Gambar 3. Data Simulasi

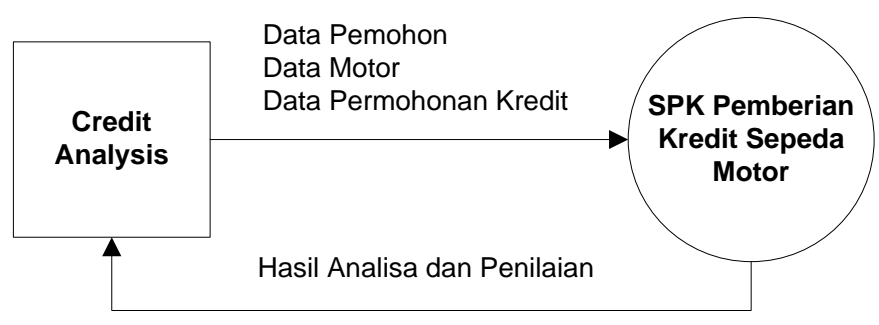

Gambar 4. Diagram Konteks

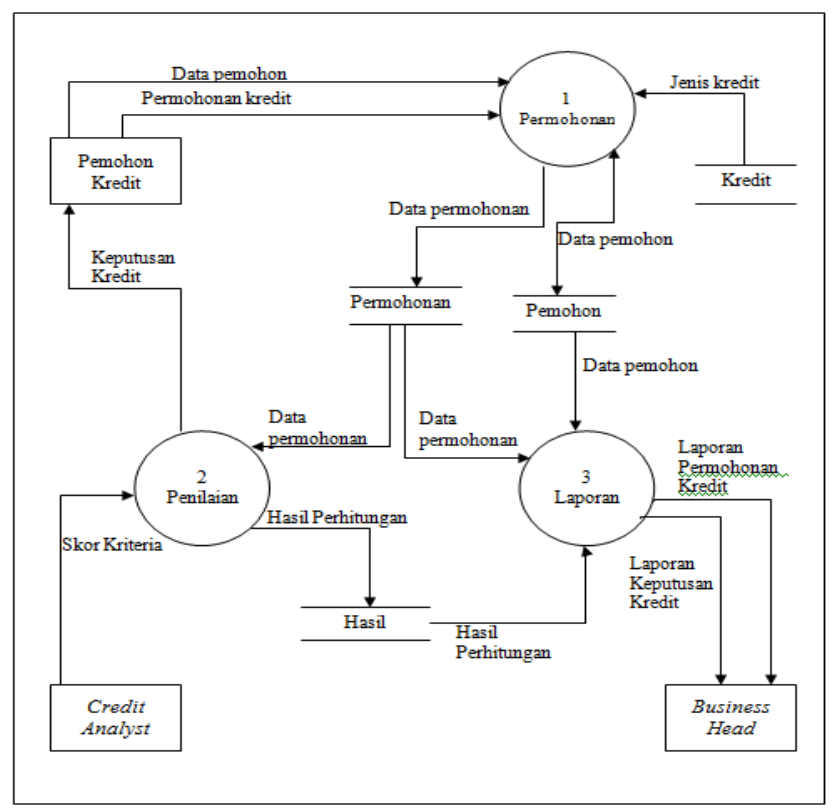

Gambar 5. DFD Level 0 
Jurnal Ilmiah Ilmu Komputer Vol. 5, No. 2, September 2019 Fakultas Ilmu Komputer

Universitas AL Asyariah Mandar

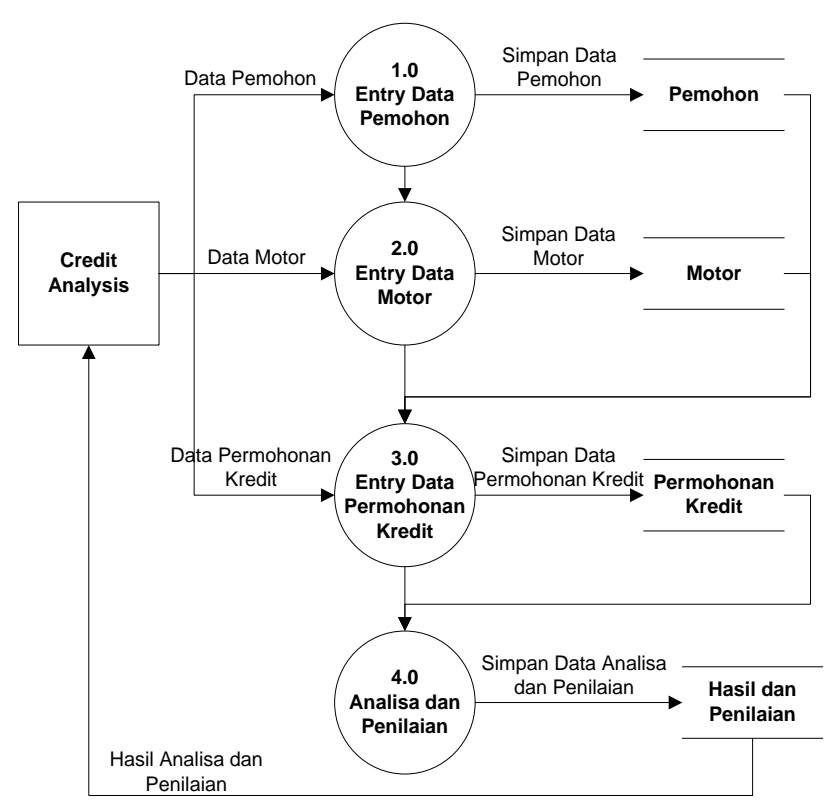

Gambar 6. DFD Level 1 SPK Kredit Motor

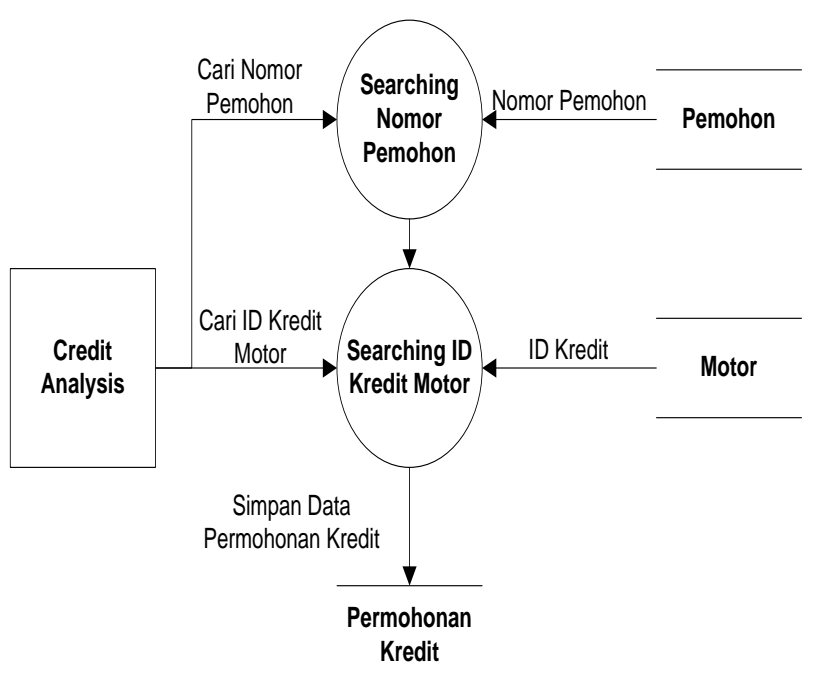

Gambar 7. DFD Level 1 Proses 3.0 Entry Data Permohonan Kredit

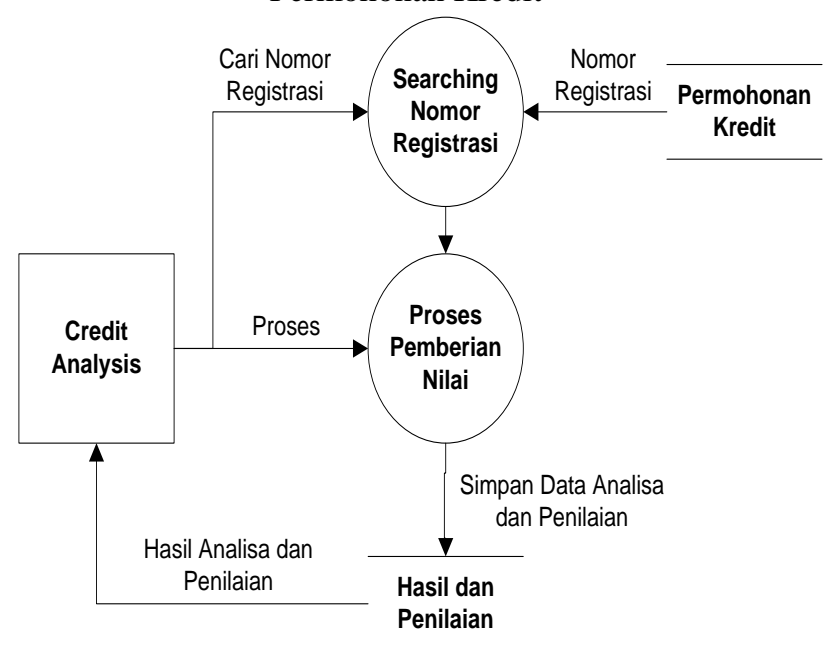

Gambar 8. DFD Level 1 Proses 4.0 Analisa dan Penilaian
(P) ISSN 2442-451X

(O) ISSN 2503-3832

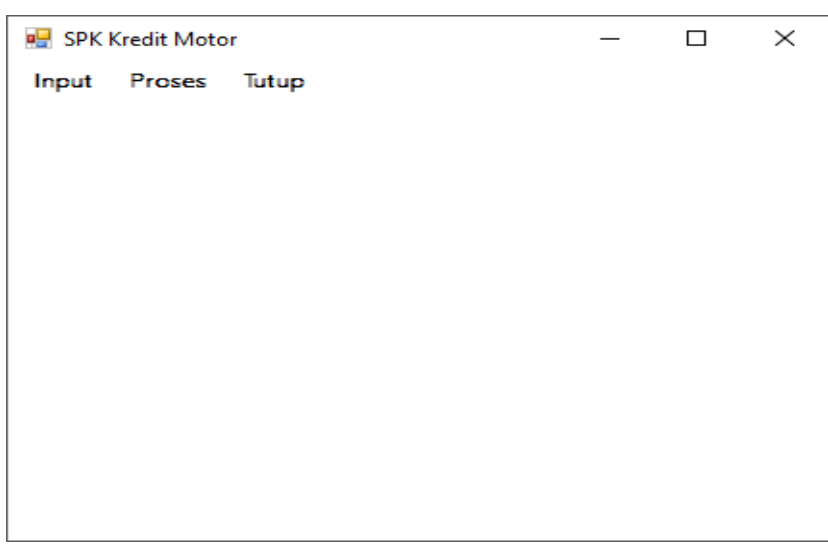

Gambar 9. Form Menu Utama

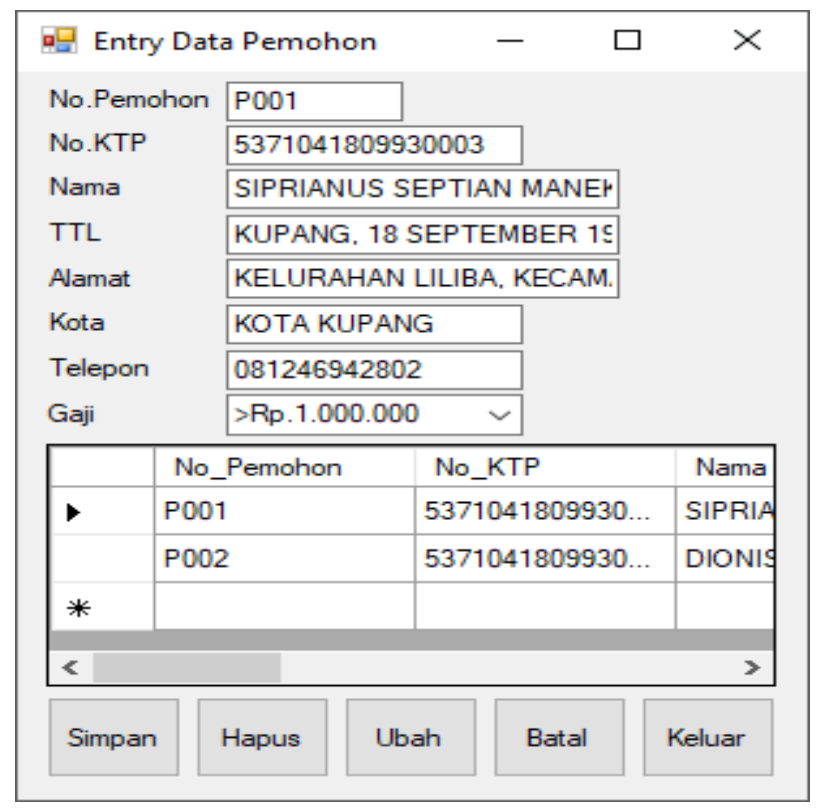

Gambar 10. Form Input Data Pemohon

吗 Entry Data Motor $\quad-\quad \square \quad \times$

\begin{tabular}{ll|} 
ID Kredit & RVF1-20-35 \\
Motor & REVO FIT F1 \\
Harga Motor & 16339000 \\
Uang Muka & 2000000 \\
\hline Lama Angsuran & 35 \\
Angsuran PerBulan & Bulan \\
\hline
\end{tabular}

\begin{tabular}{|c|c|c|c|c|}
\hline & ID_Kredit & \multicolumn{2}{|c|}{ Motor } & $\mathrm{Ha} \wedge$ \\
\hline & RVF1-15-35 & \multicolumn{2}{|c|}{ REVO FIT F1 } & 163 \\
\hline & RVF1-20-11 & \multicolumn{2}{|c|}{ REVO FIT F1 } & 163 \\
\hline 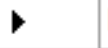 & RVF1-20-23 & \multicolumn{2}{|c|}{ REVO FIT F1 } & 163 \\
\hline \multicolumn{2}{|l|}{$<$} & \multicolumn{3}{|r|}{$>$} \\
\hline Simpan & Hapus & Ubah & Batal & Keluar \\
\hline
\end{tabular}

Gambar 11. Form Input Data Motor 
Jurnal Ilmiah Ilmu Komputer Vol. 5, No. 2, September 2019 Fakultas Ilmu Komputer

Universitas AL Asyariah Mandar

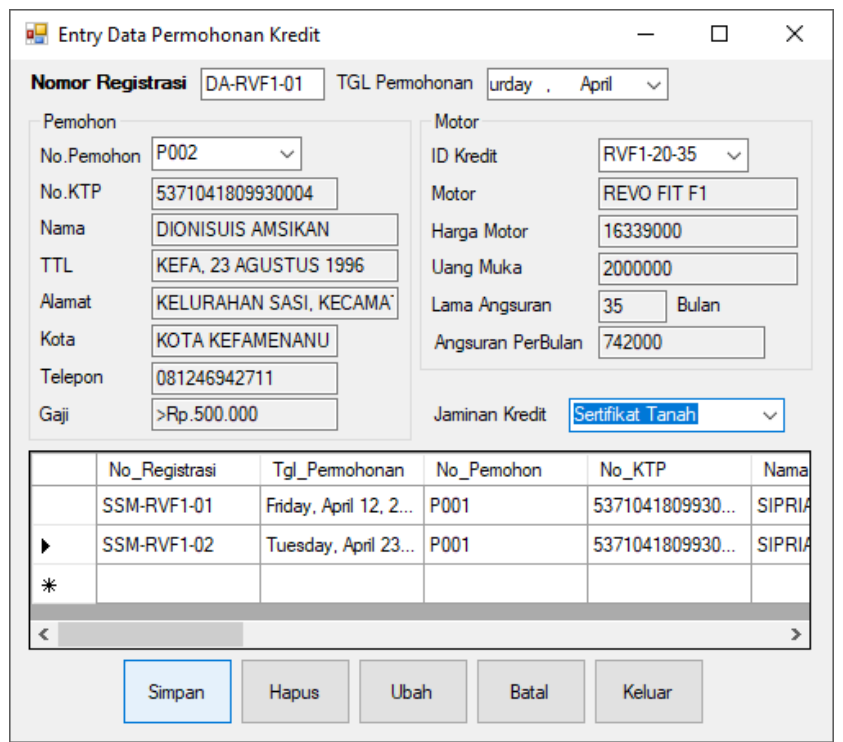

Gambar 12. Form Input Data Permohonan Kredit

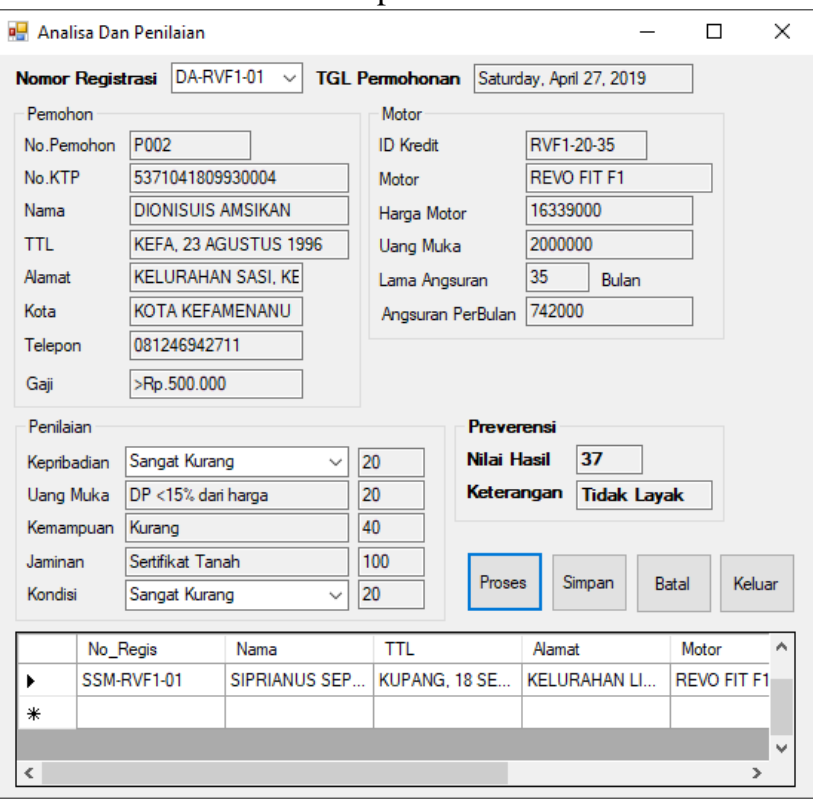

Gambar 13. Form Analisa Dan Penilaian

Tabel 1. Parameter Penilaian Kriteria C1

\begin{tabular}{|c|c|}
\hline Kriteria Pemohon & Nilai bobot \\
\hline Sangat Baik & 100 \\
\hline Baik & 80 \\
\hline Cukup & 40 \\
\hline Kurang & 30 \\
\hline Sangat Kurang & 20 \\
\hline
\end{tabular}

Tabel 2. Nilai untuk Bobot Kriteria C2

\begin{tabular}{|c|c|}
\hline Kriteria Pemohon & Nilai bobot \\
\hline DP >30\% dari harga & 100 \\
\hline DP 26-30\% dari harga & 80 \\
\hline DP 21-25\% dari harga & 60 \\
\hline DP 16-20\% dari harga & 40 \\
\hline DP <15\% dari harga & 20 \\
\hline
\end{tabular}

(P) ISSN 2442-451X

(O) ISSN 2503-3832

Tabel 3. Nilai untuk Bobot Kriteria C3

\begin{tabular}{|c|c|}
\hline Kriteria Pemohon & Nilai bobot \\
\hline Sangat Baik & 100 \\
\hline Baik & 80 \\
\hline Cukup & 60 \\
\hline Kurang & 50 \\
\hline Sangat Kurang & 30 \\
\hline
\end{tabular}

Tabel 4. Nilai untuk Bobot Kriteria C4

\begin{tabular}{|c|c|}
\hline Kriteria Pemohon & Nilai bobot \\
\hline Sertifikat Tanah & 100 \\
\hline BPKB Mobil & 75 \\
\hline BPKB Motor & 50 \\
\hline
\end{tabular}

Tabel 5. Nilai untuk Bobot Kriteria C5

\begin{tabular}{|c|c|}
\hline Kriteria Pemohon & Nilai bobot \\
\hline Sangat Baik & 100 \\
\hline Baik & 80 \\
\hline Cukup & 60 \\
\hline Kurang & 40 \\
\hline Sangat Kurang & 20 \\
\hline
\end{tabular}

Tabel 6. Sampel Kriteria Pemohon

\begin{tabular}{|c|c|c|c|}
\hline \multirow{2}{*}{ Kriteria } & \multicolumn{3}{|c|}{ Alternatif } \\
\cline { 2 - 4 } & $\begin{array}{c}\text { Kriteria } \\
\text { Macet }\end{array}$ & Mr.Siprianus & $\begin{array}{c}\text { Kriteria } \\
\text { Lancar }\end{array}$ \\
\hline C1 & Baik & Baik & Sangat Baik \\
\hline C2 & $\begin{array}{c}<\text { DP 15\% } \\
\text { C3 }\end{array}$ & DP 16-20\% & DP >30\% \\
\hline C3 & Cukup & Cukup & Sangat Baik \\
\hline C4 & BPKB & BPKB motor & Sertifikat \\
& motor & & Tanah \\
\hline C5 & Cukup & Sangat Baik & Sangat Baik \\
\hline
\end{tabular}

Tabel 7. Rating Kecocokan Alternatif pada kriteria

\begin{tabular}{|c|l|l|l|l|l|}
\hline \multirow{2}{*}{ Alternatif } & \multicolumn{5}{|c|}{ Kriteria } \\
\cline { 2 - 6 } & $\mathbf{C 1}$ & $\mathbf{C 2}$ & $\mathbf{C 3}$ & $\mathbf{C 4}$ & C5 \\
\hline Macet & 80 & 20 & 60 & 50 & 60 \\
\hline Mr.Siprianus & 80 & 40 & 60 & 50 & 100 \\
\hline Lancar & 100 & 100 & 100 & 100 & 100 \\
\hline
\end{tabular}

\subsection{Singkatan dan Akronim}

SAW (Simple Additive Weighting) dan PT.NSS (Nusantara Surya Sakti)

\subsection{Formula}

$r_{i j}\left\{\begin{array}{l}\frac{x_{i j}}{\operatorname{Max}_{i\left(x_{i j}\right)}}, \text { Jika } j=\text { atribut keuntungan }(\text { benefit }) \\ \frac{\operatorname{Min}_{i\left(x_{i j)}\right)}}{x_{i j}}, \text { Jika } j=\text { atribut biaya }(\text { cost })\end{array}\right.$ 


$$
\begin{aligned}
V_{i} & =\sum_{j=0}^{n} w_{j} r_{i j} \\
R_{i j} & =\frac{C_{i j}}{\operatorname{Max} \mathrm{C}_{i j}}
\end{aligned}
$$

\section{METODE YANG DIUSULKAN}

Penelitian ini dilakukan pada bulan April - Agustus 2019 di PT NSS Cabang Kefamenanu.

Hardware yang digunakan berupa laptop dengan Spesifikasi Minimal Intel Core i5-6200U 2.8GHz, RAM 4GB, VGA NVIDIA G-Force 930MX, dengan Software antara lain: Sistem Operasi Window 7/8//10 Pro 64 bit, Microsoft Visual Studio 2008, Notepad++ versi 6.88.

Bahan yang digunakan dalam penelitian ini adalah data nasabah pemohon kredit dengan 5 kriteria sebagai input yaitu karakter nasabah (Character), kapasitas melunasi kredit (Capacity), kemampuan modal yang dimiliki nasabah (Capital), jaminan yang dimiliki nasabah untuk menanggung resiko kredit (Collateral) dan kondisi keuangan nasabah (Condition).

Prosedur penelitian meliputi :

1. Pengumpulan Data : Tahapan ini merupakan tahapan dasar dalam penelitian ini yaitu untuk melakukan survey terlebih dahulu mengenai perusahaan khususnya tentang proses bisnis yang ada di perusahaan.

2. Identifikasi Masalah : Tujuan dari tahap ini yaitu untuk mengidentifikasi dan menganalisa permasalahanpermasalahan yang akan diteliti. Hasil dari tahapan ini yaitu adanya rumusan masalah, batasan masalah, tujuan penelitian, dan manfaat penelitian.

3. Studi Literatur : Studi literatur merupakan kegiatan mencari referensi teori yang relevan secara literatur serta menganalisis dokumen-dokumen yang berhubungan dengan kasus atau permasalahan yang akan diteliti. Dokumen-dokumen tersebut bisa berupa teori dan bisa pula berupa hasil penelitian yang sebelumnya telah dilakukan berdasarkan masalah yang akan diteliti.

4. Analisis Data : Terdapat 5 variabel kriteria penentu pemberian kredit motor pada kantor NSS Cabang Kefa yang diperoleh dari hasil interview yaitu: Character(karakter),Capital(Modal/Uangmuka),Capacit y(kapasitas/Kemampuan), Collateral(jaminan),dan Condition(kondisi). Setelah mendapatkan nilai crips setiap kriteria dari masing-masing konsumen, langkah selanjutnya adalah normalisasi menggunakan persamaan (1), karena setiap nilai yang diberikan pada setiap alternatif di setiap kriteria merupakan nilai kecocokan (nilai terbaik adalah nilai terbesar) maka semua kriteria yang diasumsikan merupakan jenis kriteria keuntungan (benefit). Langkah terakhir adalah menghitung nilai perankingan $\mathrm{V} \_\mathrm{i}$ menggunakan persamaan (2) untuk menentukan kelayakan pemberian kredit.

5. Desain Sistem : Pada tahap ini dilakukan desain Data Flow Diagram (DFD) untuk menunjukkan keseluruhan sistem dimana semua external entity langsung dihubungkan dengan satu proses utama pada sistem tersebut, dan Entity (Relationship Diagram (ERD) untuk mengetahui hubungan antar entitas. Tahapan dilanjutkan dengan perancangan antarmuka sistem. Perancangan antarmuka ini dilakukan untuk merancang tata letak sistem sesuai dengan analisis kebutuhan sistem.

6. Implementasi Database dan Pembuatan Program : Pada tahap ini dilakukan coding program yang dimulai dengan pembuatan database. Kemudian dilanjutkan dengan pembuatan program berbasis aplikasi standalone.

7. Pengujian dan Analisis Hasil Penelitian : Pada tahap ini dilakukan analisis keseluruhan dari proses penelitian yang telah dilakukan, apakah hasil penelitian dapat mengatasi permasalah yang diuraikan pada tahapan awal dan apakah hasil penelitian telah sesuai dengan tujuan penelitian.

\section{HASIL PENELITIAN}

Data meliputi data primer berupa hasil penelitian lapangan dan wawancara kepada pihak Perusahaan mengenai data produk sepeda motor yang akan dikreditkan kepada konsumnen.

Adapun pembobotan pada masing-masing 5 variabel kriteria tersebut antara lain: Karakter $(\mathrm{C} 1)=25 \%$, Uang muka $(\mathrm{C} 2)=10 \%$, Kapasitas $(\mathrm{C} 3)=45 \%$, Jaminan $(\mathrm{C} 4)=$ $10 \%$, Kondisi $(\mathrm{C} 5)=10 \%$. Format prefensi pada sistem pendukung keputusan ini adalah sebagai berikut:

a. C1 yaitu Karakter. Ada beberapa parameter yang digunakan untuk melakukan penilaian karakter konsumen. Parameter penilaian tersebut ditampilkan pada tabel 1. Hasil score meter tersebut akan menjadi nilai C1 konsumen yang didapatkan dari hasil verifikasi.

b. C2 yaitu Modal/uang muka. Capital atau modal konsumen diihat dari besarnya jumlah modal yang dikeluarkan pada usaha yang dimiliki konsumen yang penilaiannya ditampilkan seperti pada Tabel 2.

c. C3 yaitu Kapasitas. Kapasitas konsumen ditentukan oleh perbandingan antara total angsuran perbulan dibandingkan dengan penghasilan bersih konsumen. Perbandingan tersebut akan menjadi parameter pada untuk penilaian C3 yang ditampilkan seperti pada Tabel 3.

d. C4 yaitu Jaminan, dilihat dari apa yang dijaminkan oleh konsumen yang penilaiannya ditampilkan seperti pada Tabel 4.

e. C5 yaitu Kondisi, keadaan usaha yang dimiliki oleh konsumen. Penilaian dari keadaan usaha ditampilkan seperti pada Tabel 5.

Berdasarkan kriteria dan rating kecocokan setiap alternatif pada setiap kriteria yang telah ditentukan, selanjutnya penjabaran alternatif setiap kriteria yang telah dikonversikan dengannilai crips. Perhitungan berdasarkan 
Jurnal Ilmiah Ilmu Komputer Vol. 5, No. 2, September 2019 Fakultas Ilmu Komputer

Universitas AL Asyariah Mandar

contoh kasus seperti pada tabel 6 diambil sample pemohon kredit dengan nama "Mr Siprianus". Berdasarkan tabel 6 diambil 2 kriteria, yaitu kriteria kredit macet dan kriteria kredit lancar. Dua titik tersebut digunakan untuk perbandingan skor dari data "Mr.Siprianus".Berdasarkan data di atas, dibentuk matriks keputusan dengan label $[\mathrm{X}]$ yang dikonversikan dengan nilai crips, seperti tabel 7 .

Bobot kriteria sama dengan di atas, yaitu: $\mathrm{C} 1=25 \%$; $\mathrm{C} 2=10 \% ; \quad \mathrm{C} 3=45 \% ; \mathrm{C} 4=10 \% ; \quad$ dan $\quad \mathrm{C} 5=10 \%$, maka penyelesaiannya adalah sebagai berikut:Vektor bobot $[W]=\{25,10,40,45,20\}$ membuat matriks keputusan $X$, dibuat dari tabel kecocokan sebagai berikut:Vektor bobot $[\mathrm{W}]=\{25,10,40,45,20\}$ membuat matriks keputusan $X$, dibuat dari matriks kecocokan sebagai berkut :

$$
X=\left[\begin{array}{ccccc}
80 & 20 & 60 & 50 & 60 \\
80 & 40 & 60 & 50 & 100 \\
100 & 100 & 100 & 100 & 100
\end{array}\right]
$$

Melakukan proses penilaian dengan cara mengalikan matriks ternormalisasi (R) dengan nilai bobot (W).

$$
\mathrm{R}=\left[\begin{array}{lllll}
0,2 & 0,2 & 0,3 & 0,5 & 0,2 \\
0,8 & 0,4 & 0,6 & 0,5 & 1 \\
1 & 0,2 & 1 & 1 & 1
\end{array}\right]
$$

Terakhir menentukan nilai preverensi untuk setiap alternatif (Vi) dengan cara menjumlahkan hasil kali antara matriks ternormalisasi (R) dengan nilai bobot (W). Penjumlahan hasil kali matriks ternomalisasi menghasilkan angka sebagai berikut:

$\mathrm{V} 1=(25)(0,8)+(10)(0,2)+(45)(0,6)+(10)(0,5)+(10)(0,6)=58$

$\mathrm{V} 2=(25)(0,8)+(10)(0,4)+(45)(0,6)+(10)(0,5)+(10)(1)=66$

$\mathrm{V} 3=(25)(1)+(10)(1)+(45)(1)+(10)(1)+(10)(1)=100$

Dari perhitungan tersebut diambil kesimpulan bahwa nilai V1 dan V3 adalah nilai statis yang berubah hanya jika bobot kriteria diubah, sedangkan nilai V2 adalah nilai pemohon kredit. Nilai V1 merupakan nilai minimum dimana kredit macet mungkin terjadi dan V3 merupakan nilai maksimum dimana kredit berjalan lancar, sedangkan nilai V2 merupakan nilai "Mr.Siprianus". Oleh karena itu, nilai kelayakan kredit berada diatas angka V1 dan dibawah / sama dengan V3. Dalam kasus ini, nilai kelayakannya adalah $59-100$, jadi Mr.Siprianus dinyatakan layak menerima kredit dengan nilai 66.

\section{KESIMPULAN}

Sistem pendukung keputusan untuk menentukan kelayakan pemberian kredit sepeda motor pada PT NSS cabang Kefamenanu membantu dalam memberikan rekomendasi dan pertimbangan dalam pengambilan keputusan realisasi kredit berdasarkan kriteria yang telah ditentukan oleh pihak perusahaan.

Beberapa saran terkait dengan penelitian ini adalah sebagai berikut :1.Peneliti hanya membatasi pada 5 nilai pada setiap kriteria, yaitu Sangat Kurang, Kurang, Cukup, Bagus dan Sangat Bagus. Untuk pengembangan sistem dapat ditambah beberapa variabel nilai lain yang mungkin dapat memperkuat dalam pengambilan keputusan.2.Sistem yang dirancang merupakan sistem pendukung keputusan pemberian kredit sepeda motor, untuk pengembangan sistem dapat dilakukan dengan merancang sistem informasi pembayaran kredit motor pada pemohon kredit yang telah diterima.3.Sistem berbasis web menjadi pengembangan yang tepat agar aplikasi dapat diakses dimana saja, mengingat bahwa PT NSS banyak memiliki kantor cabang di NTT.

\section{UCAPAN TERIMA KASIH}

a. Kepada Lembaga Penelitian dan Pengabdian (LPPM) Universitas Timor yang telah memberikan hibah penelitian dosen pada tahun anggaran 2018/2019

b. PT.NSS yang telah membantu memberikan data dan tempat untuk studi kasus dalam penelitian ini.

\section{Daftar Pustaka}

[1] Sri Kusumadewi, 2006, Fuzzy Multi-Attribute Decision Making (Fuzzy MADM), Graha Ilmu, Yogyakarta.

[2] Efraim Turban.dkk, 2005, Decision Support Systems and Intelligent Systems, edisi Bahasa Indonesia jilid 1.Penerbit Andi.Yogyakarta.

[3] Rosnani Ginting., 2014, Konsep dan Aplikasi Sistem Pendukung Keputusan, USU Press, Medan.

[4] Hariyani, I.,Toruan, R.L.2010.Restrukturisasi dan Penghapusan Kredit Macet.Elex Media Komputindo.

[5] Sri Kusumadewi, Hari purnomo., 2010, Aplikasi Logika Fuzzy untuk pendukung Keputusan, Graha Ilmu, Yogyakarta.

[6] Kelen, Y. P. K., 2015, Pemilihan Wilayah Alternatif Terbaik Dengan Menggunakan Metode Multi Criteria Decision Making, JURNAL ILMIAH ILMU KOMPUTER, 1(1), 19-26.

[7] Kelen, Y. P. K., \& Sikas, O. R., 2019, Sistem Penjadwalan Distribusi Produk Sepeda Motor Menggunakan Metode Distribution Requirement Planning (DRP) Pada PT. Nusantara Surya Sakti (NSS) Cabang Kefamenanu. SAINTEKBU, 11(1), 27-39. 